\title{
Enhancing the quality of Final Year Projects in Computing through weekly written tasks
}

\section{Marion Bowman}

University of Bradford, UK

\section{Andrea Cullen}

University of Bradford, UK

\begin{abstract}
Writing can be used as a means of engaging students in their studies, leading to greater time spent on the subject, greater interest in the subject and ultimately better grades. The intervention discussed in this paper involved the setting of weekly written tasks embedded within the lecture strand of a Computing Final Year Project (FYP) module. The aims behind this 'thinking through writing' intervention were to enhance students' ability to produce high quality projects and written project reports, as well as to improve students' ability to manage their time while completing their projects. Results from this study showed that there was a significant positive relationship between weekly task marks and project marks, however, only $57 \%$ of the cohort were classed as being 'engaged' in doing the written tasks (as they had completed seven or more of the ten tasks). In addition, tentative results showed that the weekly task intervention seemed to be associated with better quality written project reports. Also, students generally seemed to regard the weekly written tasks as useful for time management, in terms of completing their written project reports. However, this collaborative intervention did raise questions about the link between learning and writing in this context. Finally, a number of recommendations are made for 'learning through writing' interventions in FYP modules.
\end{abstract}

Keywords: writing to learn; technical writing; Final Year Project; computing, engineering; time management; embedded writing development. 


\section{Introduction}

Writing is perhaps the most powerful means we have with which to fully engage our students with their studies. (Deane and O'Neill, 2011b, p.268)

The starting point for the collaborative project that will be described in this paper, is that writing is a manifestation of thinking, and the more practice students are given with writing in their discipline, the greater their engagement in the subject (Light, 2001; Bean, 2011; Deane and O'Neill, 2011b). Engagement in this context is taken to encompass the time students spend on the course content, their perception of the intellectual stimulation presented by the course, and their interest in the subject material (English et al., 1999; Light, 2001). It is argued then, that students who are more engaged in their studies, learn more and perform better, leading to better grades. The link between engagement and positive learning outcomes, such as critical thinking and better grades, is supported by the empirical findings of a number of studies (Carini et al., 2006). Thus, whilst students are 'learning to write' they are also 'writing to learn' (English et al., 1999, p.222).

As 'thinking and writing are integral' (Deane and O'Neill, 2011a, p.4), it could be argued that disciplinary knowledge and its associated specific writing practices are also inseparable. Writing is thus practiced more effectively as authentic tasks embedded within the subject material of a module, not as an additional 'bolt on' study skills course (Wingate, 2006). The explicit teaching of genre-specific academic writing from within a discipline, with a subject specialist playing a key role, is consistent with the Writing in the Disciplines approach (WiD) (Deane and O'Neill, 2011a; 2011b).

WiD interventions often involve the staging of assessed pieces of writing in order to maximize opportunities for formative feedback (Deane and O'Neill, 2011a; 2011b). Giving feedback, or feedforward, is the most important aspect of assessment in terms of enhancing attainment, as it can promote critical thinking and improve writing quality (Black and Williams 1998, cited Bloxham and Boyd, 2007; Dean and O'Neill, 2011a; 2001b). However, not all feedback is equal. An advantage of formative feedback, over summative feedback, is that it has the potential to encourage student experimentation due to the fact that formative or staged assessment tasks represent a low stakes activity (Irons, 2008). In order for formative feedback to be effective, it must be timely, be of an appropriate quality, be understandable and be valued by students. The aim of this kind of feedback is to show 
the student the difference between their performance and the desired level of performance, as well as to point out areas for improvement and to make practical suggestions on how to change (Irons, 2008). Effective formative feedback should also invite two-way communication with the marker (Irons, 2008).

Whilst the literature discussed above promotes the use of staged writing tasks with formative feedback as tools for increasing student engagement, learning and attainment, it must be borne in mind that Computer Science (CS) students are actually very reluctant writers. According to Becker (2008, p.16) CS students are 'famous for their unwillingness to write'. Many students studying engineering (a close disciplinary cousin of computing) may not have done much writing since their GCSE's (Ahearn, 2006). In the experience of this author, a similar situation exists for students doing CS. In addition, some computing students may actually have chosen this particular discipline in the hope of avoiding writing (Becker, 2008). Furthermore, this reluctance to write can become more entrenched, as it is rare for computing students to be given writing tasks in their courses (Becker, 2008; Cilliers, 2012). When written tasks are given, there tends to be very little explicit support or guidance (Skinner and Mort, 2009).

Most computing and engineering programmes require their third year students to undertake a Final Year Project (FYP) or capstone project (term used in the USA) (Jawitz et al., 2002; Olsson et al., 2003; Kilpatrick, 2007). These FYPs are important as they are often used by external examiners as an indicator of the standard of the whole degree programme, (Rasul et al., 2009). Final year students doing their projects need to employ a wide range of abilities and competencies, including drawing on their writing skills in order to produce a lengthy project report. Given that there are often very few written tasks in computing degree courses until the final year, students doing their FYPs have to negotiate a rather steep learning curve in this area (Kortarts et al., 2010). In addition, there is usually not much opportunity to improve the quality of an FYP report as it is usually summatively assessed with little feedback being given prior to completion (Kortsarts et al., 2010). Thus, FYPs often represent a 'leap in expectations of students' and may also be a form of 'curricular disconnect' with the rest of the degree course (Dym et al., 2005; Rasul et al., 2009).

To further complicate matters, FYP modules themselves are extremely complex units of learning. They exist in a variety of forms and aspire to meet a range of different aims. In a 
survey of five different engineering departments in one institution, Jawitz et al. (2002) identified three broad aims for FYPs: i.e. to teach students research skills, professional skills or discipline-specific skills. These divergent aims are based on different assumptions, i.e. whether the project serves as a preparation for postgraduate research, as an apprenticeship for industry or as a way to deepen the students' knowledge base (Olsson et al., 2003). It is common for an FYP programme to attempt to address all these aims at once, leading to difficulties in designing and organizing the programme (Olsson et al., 2003). In fact the 'problematic nature' (Rasul et al., 2009, p.206) of FYP modules on a number of levels, is a theme that emerges from the limited amount of literature devoted to this topic (see Table 1).

\section{Issues identified in the FYP module: CM-0347K}

The intervention discussed in this paper came about as a result of a collaborative partnership between the module co-ordinator of the Computing FYP module at the University of Bradford (module code: CM-0347-K) and a learning developer from the central Learning Development Unit at the same institution. The first issue identified by the module co-ordinator was that the FYP students had difficulty in producing written project reports and portfolios that were sufficiently rigorous and academic in style. This concern was echoed by external examiner comments (External Examiner, 2009). External examiners also commented that in relation to the distribution of awards 'we are seeing a very long tail' (External Examiner, 2010). This distribution may be linked with the unique student population at the University of Bradford, the majority of whom have English as a second language. In addition, project supervisors felt that students had difficulty in managing their time whilst doing their projects (Project Supervisor A and B, 2010). Other issues identified were that there seemed to be variability in the student experience of supervision, and that not all students paid attention to the formative comments made on their mid-term reports. These issues emerged from an in-depth module evaluation of CM0347-K undertaken by the first author of this paper. The module evaluation then led to the collaborative intervention that is discussed in this paper. 
Table 1. A number of issues common to FYP modules across institutions.

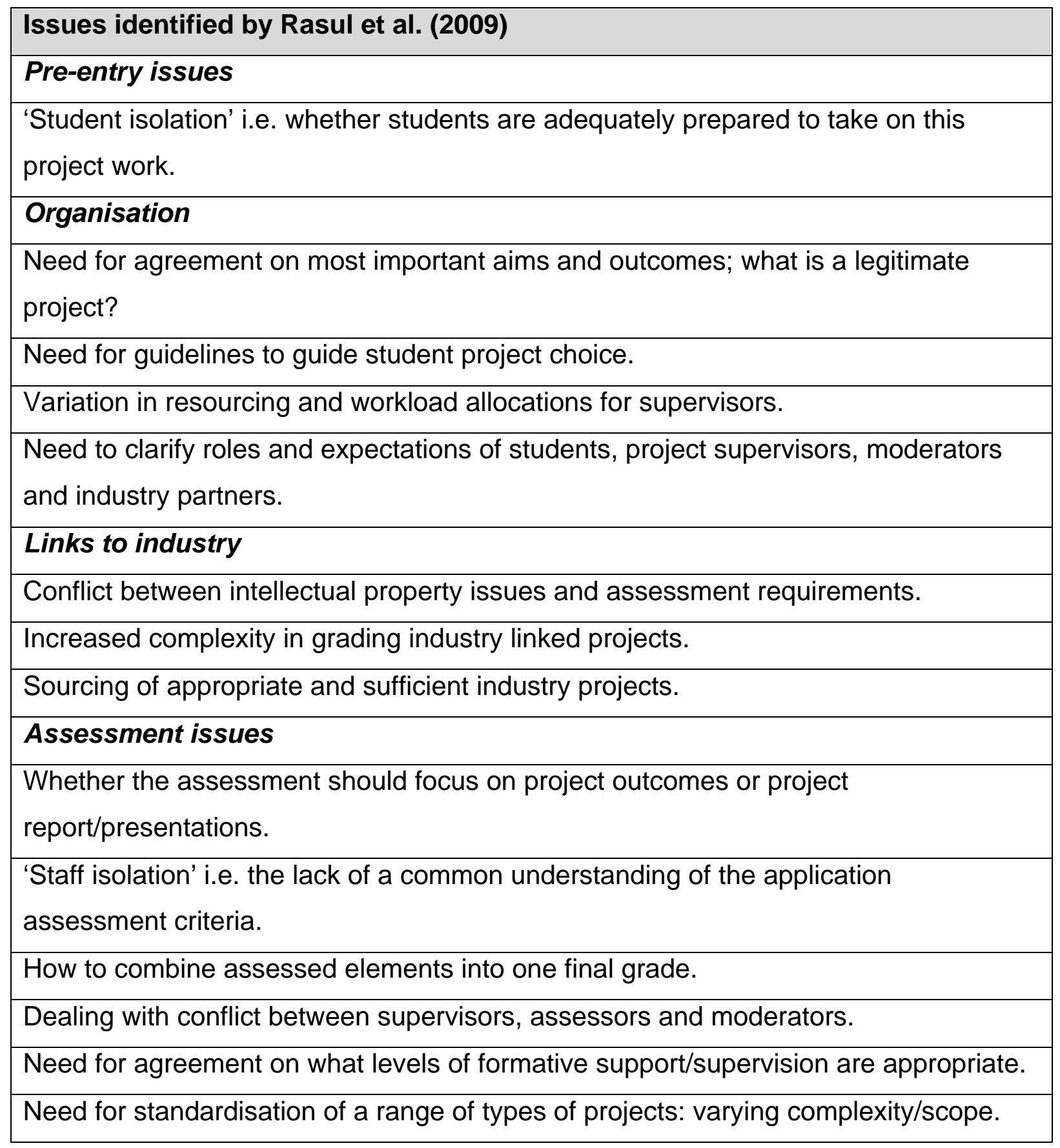

\section{The aims of the intervention}

The overarching aim of this intervention was to improve the quality of student projects and project reports through weekly written tasks accompanied by detailed formative feedback. By bringing these weekly tasks into the lecture strand of the module, it was also hoped that the regular and detailed feedback would help to ameliorate the variability of supervision and assist in engaging and supporting weaker students. The objectives of the intervention 
were that at the end of the 2010/11 year, the Computing FYP students would be better able to:

1. Produce high quality projects as evidenced by improved student grades.

2. Write a high quality academic project report.

3. Manage their time effectively whilst completing a large project.

\section{The intervention}

There are essentially three spheres of activity within the Computing FYP module CM-0347K, viz, the student's independent project work, the supervision of this work by a large number of supervisors, and general support provided within the lecture strand of the module by the module co-ordinator. The module is assessed by means of a practical project demonstration, a presentation and a written project report. These modes of assessment together make up $75 \%$ of the module mark. In 2010/11 the lecture strand of the module was restructured to include weekly written tasks that matched the content covered in the lectures (see Table 2). These weekly tasks counted for a small proportion of the project report mark and were largely formative in nature. In addition, students could use drafts of their weekly tasks and their feedback as evidence of learning in their portfolios. The assessed portfolios make up the remaining $25 \%$ of the module mark.

The weekly tasks were run as follows: students brought in their task in paper form at the start of each lecture and then peer marked the tasks during the session. Tasks were handed in at the end of the lecture and returned the following week having been marked and annotated with detailed individual comments. General feedback on task performance was also given during the following lecture. The aim of the individual, peer and general feedback was to try to promote the development of complex reasoning in writing, by focusing on the need to use evidence to justify design choices in a convincing way. These choices related to applications, programming languages, methodology and other design features. 
Table 2. The lectures and weekly tasks for the 2010/11 academic year.

\begin{tabular}{|c|c|}
\hline Lectures & Weekly tasks \\
\hline \multicolumn{2}{|l|}{ Semester 1} \\
\hline $\begin{array}{l}\text { 1. General information about your } \\
\text { project }\end{array}$ & (no task) \\
\hline $\begin{array}{l}\text { 2. Assessment for this module: } \\
\text { portfolio, reflection and self- } \\
\text { assessment }\end{array}$ & Project choice form \\
\hline $\begin{array}{l}\text { 3. Project planning and supervisor } \\
\text { allocation }\end{array}$ & Project specification \\
\hline 4. Researching and referencing & $\begin{array}{l}\text { List of literature/resources relevant to } \\
\text { project }\end{array}$ \\
\hline 5. Writing your literature review & First draft of literature review \\
\hline 6. Project development methodologies & $\begin{array}{l}\text { First draft of system development } \\
\text { methodology }\end{array}$ \\
\hline 7. Time management and Gantt charts & First draft of Gantt Chart \\
\hline $\begin{array}{l}\text { 8. Doing a presentation about your } \\
\text { project }\end{array}$ & First draft of project presentation \\
\hline \multicolumn{2}{|l|}{ Semester 2} \\
\hline 1. Writing your project report & Contents page of final report \\
\hline 2. Data protection in your project & $\begin{array}{l}\text { First draft of summary of lecture on } \\
\text { either data protection or ethics }\end{array}$ \\
\hline 3. Ethical considerations in your project & $\begin{array}{l}\text { Second draft of summary of lecture on } \\
\text { either data protection or ethics and a } \\
\text { reflective piece of writing to show the } \\
\text { difference between the two drafts }\end{array}$ \\
\hline $\begin{array}{l}\text { 4. External speaker: computing at } \\
\text { Morrisons }\end{array}$ & $\begin{array}{l}\text { (no task, work on implementation, } \\
\text { report and portfolio) }\end{array}$ \\
\hline 5. Preparing your CV & (no task, ongoing work on project) \\
\hline 6. Open session: questions & (no task, ongoing work on project) \\
\hline 7. Open session: questions & (no task, ongoing work on project) \\
\hline
\end{tabular}


The lectures themselves actually took the form of activity-based sessions. In these sessions, students worked through text-based activities in pairs and analysed examples of good and poor student writing relating to FYPs. The fact that there were 104 students in this cohort, each with a different individual project and following one of eight different degree paths, meant that there were some challenges associated with this intervention. There was a significant increase in the amount of marking due to the addition of weekly tasks, and also a large number of students typically stayed after the lectures to ask the module co-ordinator individual questions. During this intervention, the module co-ordinator and the learning developer shared the marking, teaching and collating of general feedback. It is interesting to note that weekly tasks were still being used in this module in the 2011/12 academic year, but with some modifications in the number and timing of tasks as suggested by student feedback.

\section{Methods}

The intervention was evaluated in relation to the aims and objectives, stated earlier, by means of a pragmatic mixed methods approach (Teddlie and Tashakkori, 2009). Both quantitative and narrative data were used sequentially as new issues in the data emerged. Firstly, a questionnaire containing both open and closed questions was administered to all students during a lecture towards the end of the first semester, when students had completed seven weekly tasks. The aim of the questionnaire was to ascertain whether students perceived the weekly tasks as having had an impact on the quality of their projects and their management of time during the project. Upon completion, the results of the closed questions in the questionnaire were quantified and the open questions were categorised and quantified. A number of unexpected findings emerged from the results of this questionnaire, and this led to a focus group interview being conducted in the second semester, in order to get a richer picture of students' FYP experience.

The focus group interview participants consisted of a self-selected sample of ten students. The interviews were conducted by three trained third year student interns who were doing other degree courses at the university. After the interview, the data was transcribed carefully by the first author of this paper in order to keep to the exact words of the participants, paying careful attention to overlapping speech, interruptions and murmured agreement or dissent. The gender and degree path of each participant was also noted. 
After transcription, the interview data was categorised and coded. Each code was tabulated to show links to other coded themes (see example in Table 9). This tabulated data was then used to produce a concept map to show the strength of the themes and the links between them (see Figure 1). The transcript, concept map and tabulated results were later verified by the original student interviewer as an accurate reflection of what was discussed in the focus group.

On completion of the 2010/11 academic year, students' marks for the project itself, the project report, the portfolio and the weekly tasks were compared to determine if any correlation existed between these results. Kendall's Tau is a non-parametric correlation statistic. This correlation statistic was selected for use here as it is suitable for small data sets that are not normally distributed, and is thought to be more accurate than the more popular Spearman's Rho correlation statistic (Field, 2009). Test results can be considered as one-tailed or two-tailed. As the working hypothesis of this study suggests a direction for this difference (i.e. that participation and success in weekly tasks should suggest improved grades) a one-tailed test was conducted here.

The three sources of data: the questionnaire from semester 1 , the semester 2 focus group interview and the statistical analysis of final grades were then triangulated in order to evaluate the intervention against the original stated aims.

\section{Results and discussion}

\section{Higher quality projects as evidenced by students' project marks}

The principal aim of this intervention was to improve the quality of student projects through weekly written tasks, by taking a 'learning through writing approach' (English et al., 1999). In designing the intervention, it was assumed that writing could be used as a powerful way to increase engagement in the subject (Deane and O'Neill, 2011b). This was thought to be especially important in the context of this module which contained a large number of weaker students (External Examiner, 2010). However, it is interesting to note that of the 104 students, 58 could be classed as 'engaged' in the weekly tasks (these students did seven out of ten weekly tasks or more), as compared to 46 students who were not engaged (these students handed in six or less weekly tasks out of a possible ten). So, bearing in mind the large number of 'not engaged' students, the question must be raised 
as to whether using these kinds of written tasks is the best way of engaging CS students, as writing is often CS students' least favourite activity.

Having said this, though, from the test results obtained, there was a significant positive relationship between the total written task marks and the project mark with Kendall's correlation coefficient being 0.278 with $\mathrm{p}=000$ one-tailed. In addition, the students classified as engaged in the weekly tasks achieved an average project mark of $59.96 \%$ as compared to not engaged students, who scored an average of $48.13 \%$ for their projects. As would perhaps be expected, there was a significant positive relationship between the total weekly tasks marks and the portfolio marks, being 0.358 with $p=000$ one-tailed (the portfolio includes evidence from the weekly tasks). Thus, as shown above, there were significant positive relationships between the results of the weekly tasks and the project and portfolio marks. However, it must be borne in mind that only $54 \%$ of the students fully engaged with the weekly tasks. So, does this result indicate that more engaged students are likely to do better anyway? It is the perception of the Head of the Computing Department (Ridley, 2012) that the weekly task intervention improved the quality of students' projects for average to good students, but that this intervention did not make a significant difference to the 'long tail' of weaker students.

Once again, whilst the results described above did show a positive correlation between weekly task marks and project marks, this result may warrant closer scrutiny. It is interesting to note that the view of the module co-ordinator and a number of supervisors on this module was that students could get a good mark for the written components of their FYP if they had given a successful project demonstration, even if their writing was of a poor quality (Supervisor A, 2010; Supervisor B, 2010; Cullen, 2012). This view is supported by Ahern (2006) who noticed the same phenomenon in Engineering, and by English et al. (1999) who noticed staff marking written work by looking only for 'key words' in Accounting. The focus on content in technical subjects may mean that students can 'get away' with poor quality writing and that students may resent spending time on practising writing as they might not see the relevance of this to their degree (Ahern, 2006). Indeed, the findings of the questionnaire in this study tend to indicate that not all students saw the link between the written tasks and their project: '[the weekly tasks are] very useful, but still uncertain as to where the weekly tasks fit into the Final Year Project'. However, other students had a different view: 'the weekly tasks help us to develop own knowledge in all aspects of own project'. The results of the focus group interview (see Figure 1) illustrate 
that respondents did not specifically link the written component of their FYP with programming and their actual project.

As FYP modules are enormously complex units of learning, there could have been a number of other issues that could have had an impact on the quality of student projects. In fact, two such unexpected issues emerged from the findings of the semester 1 questionnaire. In the open questions, students raised issues to do with supervision, and the term 'prototype' was mentioned a number of times in relation to requests for further support (see Table 3). This is illustrated by the following quotation: '[I need more support with developing my] Prototype. [I need] Help classes with expert tutors in programming different languages'.

Table 3. Students' questionnaire responses to the open question 'Is there anything you would like further support with?'.

\begin{tabular}{|l|l|}
\hline Category of comments & $\begin{array}{l}\text { Number of } \\
\text { comments }\end{array}$ \\
\hline More guidance with writing the report & 7 \\
\hline More support with developing the prototype & 7 \\
\hline Supervisor issues & 6 \\
\hline More guidance with the portfolio & 4 \\
\hline General request for help (late arrivals to the module) & 4 \\
\hline More examples of the portfolio/the report & 3 \\
\hline Time management skills & 1 \\
\hline More professional speakers & 1 \\
\hline Feedback on weekly tasks in semester 2 & 1 \\
\hline More support with searching for information & 1 \\
\hline
\end{tabular}

When asked about possible areas for improvement in this module, a similar theme emerged. Twenty two per cent of the respondents who commented on this question thought that the FYP lecture strand should have a closer link to software design or wanted more guidance relating to doing their 'actual projects' (see Table 4). 
Table 4. Students' responses to the open question 'Areas for improvement in this module' in the semester 1 questionnaire.

\begin{tabular}{|l|l|}
\hline Category of comments & $\begin{array}{l}\text { Number of } \\
\text { comments }\end{array}$ \\
\hline $\begin{array}{l}\text { The timing of the weekly tasks (have the lecture on the topic } \\
\text { before doing the weekly task) }\end{array}$ & 14 \\
\hline Specific aspect, e.g. more details on doing a literature review & 6 \\
\hline More guidance with the actual project/prototype & 5 \\
\hline Closer link to software design & 4 \\
\hline More examples & 4 \\
\hline PPT slides available on BlackBoard sooner & 4 \\
\hline Longer lecture slots & 3 \\
\hline Timetable must be accurate & 1 \\
\hline No weekly tasks & 1 \\
\hline More individual marking & 1 \\
\hline Project lists available earlier & 1 \\
\hline
\end{tabular}

The theme of wanting more specialised support with software and programming languages was further amplified in the focus group interview. In fact, this emerged as the dominant theme (see Figure 1). This theme was discussed for longer than any other emergent theme. It became clear that the students interviewed had been searching for programming expertise within the body of academic staff that 'matched' their own project. They also suggested that programming should be given more emphasis in the first year of the degree, and that students should be mandated to take a particular programming module before starting their FYP's. Overall, it could be argued that the quality of a student's programming would have the potential to affect the quality of the end product and thus the grade given for their project. 


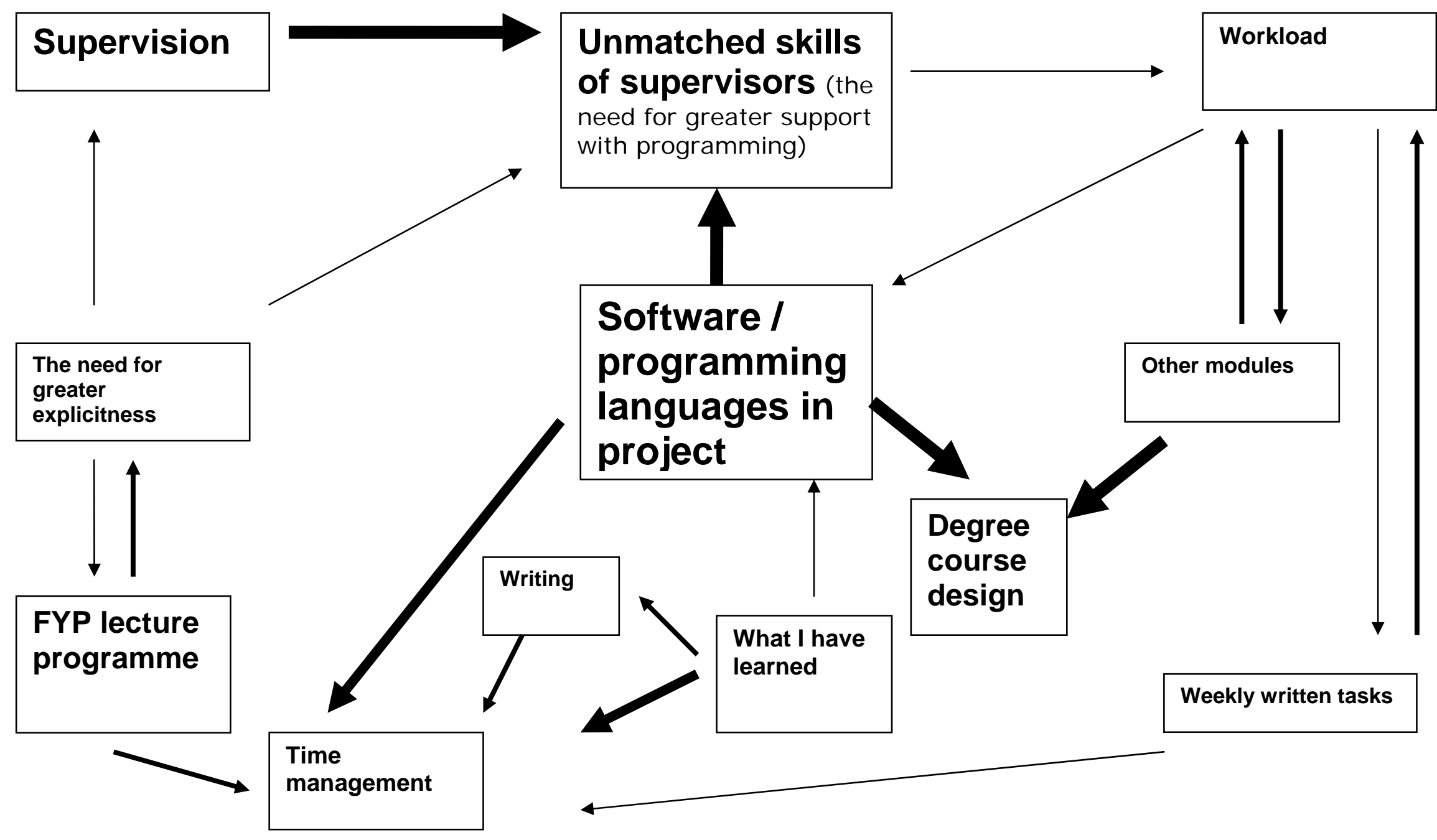

Figure 1. A thematic map of the themes emerging from the focus group interview. Key: the larger the font size, the greater the strength of the theme or link between themes. The strength of the theme was determined by the number of times the issue was mentioned during the focus group interview. 


\section{Students' ability to write a high quality academic project report}

The second objective of this study was to better prepare students to be able to write a high quality academic project report containing rigorously justified design choices. To achieve this objective, the lecture strand of the module was re-structured to more closely align to the FYP, and associated weekly written tasks were set. The results of the semester 1 questionnaire, which 75 students out of a possible 104 students completed, showed that $92 \%$ of the respondents saw the FYP lecture sessions as useful, quite useful or very useful (see Table 5). This could be regarded as a promising result as technical students are often reluctant writers (Ahearn, 2006).

Table 5. Student perceptions of the usefulness of the weekly tasks and associated feedback. Data taken from the semester 1 questionnaire.

\begin{tabular}{|l|l|l|l|l|l|}
\hline & $\begin{array}{l}\text { Very } \\
\text { useful }\end{array}$ & $\begin{array}{l}\text { Quite } \\
\text { useful }\end{array}$ & Useful & $\begin{array}{l}\text { Not } \\
\text { useful }\end{array}$ & $\begin{array}{l}\text { Did not } \\
\text { attend }\end{array}$ \\
\hline FYP lecture sessions 1- 8 & $40 \%$ & $33 \%$ & $19 \%$ & $4 \%$ & $4 \%$ \\
\hline $\begin{array}{l}\text { General feedback on } \\
\text { weekly tasks the } \\
\text { following lecture }\end{array}$ & $33 \%$ & $33 \%$ & $30 \%$ & $2 \%$ & $2 \%$ \\
\hline $\begin{array}{l}\text { Individual feedback on } \\
\text { weekly tasks the } \\
\text { following lecture }\end{array}$ & $34 \%$ & $31 \%$ & $31 \%$ & $0 \%$ & $4 \%$ \\
\hline $\begin{array}{l}\text { Peer marked feedback in } \\
\text { lectures }\end{array}$ & $13 \%$ & $35 \%$ & $29 \%$ & $16 \%$ & $7 \%$ \\
\hline
\end{tabular}

The majority of students answering the questionnaire also viewed the weekly tasks as useful (see Table 6). It is also interesting to note that $26 \%$ of the respondents identified the weekly tasks as a key strength of the FYP module in the open comments section of the questionnaire. In addition, 22\% of the sample linked the 'usefulness' of tasks and the rapid feedback to improving quality of their work (see Table 7 for quotations). It is assumed here that students are meaning the quality of their written work as opposed to their project work (as noted earlier in the results section, many students seemed to view their written work and project work as separate). 
Table 6. An analysis of the open comments from the questionnaire.

\begin{tabular}{|l|l|l|}
\hline $\begin{array}{l}\text { Weekly tasks: positive } \\
\text { comments (no. of }\end{array}$ & $\begin{array}{l}\text { Weekly tasks: mixed } \\
\text { comments }\end{array}$ & $\begin{array}{l}\text { Weekly tasks: negative } \\
\text { comments }\end{array}$ \\
\hline $\begin{array}{l}\text { Useful: helps with time } \\
\text { management (15) }\end{array}$ & Useful, but change timing (9) & $\begin{array}{l}\text { Weekly tasks are an extra } \\
\text { burden (4) }\end{array}$ \\
\hline $\begin{array}{l}\text { Useful: improves quality of } \\
\text { work (11) }\end{array}$ & $\begin{array}{l}\text { Useful, but need more } \\
\text { support (7) }\end{array}$ & $\begin{array}{l}\text { Haven't done them (1) } \\
\text { Generally useful (6) }\end{array}$ \\
$\begin{array}{l}\text { Useful, but time consuming } \\
(3)\end{array}$ & $\begin{array}{l}\text { Task instructions unclear } \\
(1)\end{array}$ \\
\hline Enjoy the tasks (3) & $\begin{array}{l}\text { Useful, but need more } \\
\text { examples (2) }\end{array}$ & $\begin{array}{l}\text { Specific aspect of task not } \\
\text { marked (1) }\end{array}$ \\
\hline learning (1) & Other comments (2) & \\
\hline $\mathbf{3 6}$ & $\begin{array}{l}\text { Useful, but what is link to } \\
\text { project (1) }\end{array}$ & $\mathbf{7 4}$ \\
\hline
\end{tabular}

Table 7. Quotations from the questionnaire that show a link between the weekly tasks and the perceived quality of students' (mostly written) work.

\section{Quotations from students:}

- Weekly tasks help to improve standard of the work by using feedback to enhance the work.

- $\quad$ Based on the feedback you can amend accordingly.

- $\quad$ Very useful and gives good ideas for the work.

- $\quad$ Really useful as it allows you to improve your work.

- I feel the tasks have been useful, feedback particularly useful in improving them.

- A very good idea which provides a good guideline on what is expected and how to achieve this.

- $\quad$ Helps us in making the project better. 


\begin{tabular}{|ll|}
\hline - & [With the weekly tasks] you also get feedback so you can rewrite it if needs to \\
be. \\
\hline$\bullet$ & Also help improve your understanding \\
\hline$\bullet$ & Literature review feedback, quite useful to develop it further \\
\hline$\bullet$ & The weekly tasks help us to develop own knowledge in all aspects of own \\
& project. \\
\hline - & The weekly tasks are quite useful as we get a chance to improve upon our \\
& drafts. \\
\hline
\end{tabular}

The questionnaire data also indicates that respondents valued the feedback given as part of the weekly tasks (see Table 5). The dominant perception here was that both the general feedback and the individual feedback on the tasks was more useful than the peer feedback (see Table 5).

Whilst students seemed to generally perceive the weekly tasks and the associated feedback as useful, Table 4 and 6 show that quite a number of students wanted to change the timing of the tasks. The design of this intervention was such that students came to the lecture sessions with a written draft relating to the topic being discussed during that session, the idea being that students would learn more after already having had an initial attempt at the task. Only one student completing the questionnaire seemed to agree with this: ' $[\mathrm{l} \mathrm{am}]$ finding it useful doing the tasks before learning about them as it gives you an incentive to look it up yourself'. Many other comments from the questionnaires indicated that students would have preferred the guidance on the task first, before making an attempt at doing a draft: 'It would be better if we had the lecture on the weekly task before the task to get a better understanding'. This feedback from students was taken into account in the design of the weekly task schedule in 2011/12.

The fact that the students in this study viewed the weekly tasks and feedback as generally useful, may be related to their relative lack of experience with academic writing; a common phenomenon in technical subjects (Ahearn, 2006). An analysis of the initial literature review written tasks showed that there was quite a bit of scope for improvement in the quality of student writing, hence the perception that the tasks had been 'useful' (a more detailed analysis of the quality of writing in these literature review tasks will be the subject of another paper). 


\section{Students' ability to manage their time effectively}

FYPs require students to be much more self-directed than in their first or second years of study. In order to successfully complete a FYP, students must draw upon significant organisational and time management skills (Rasul et al., 2009) and many students underestimate the workload associated with an FYP (Ras et al., 2007). In the initial module evaluation of the CM-0347K, supervisors raised concerns about students' time management practices. It was felt that many students were leaving important aspects of their project, including implementation and writing their report, until the final stages. Whilst the main aim behind the introduction of the weekly written tasks in this intervention was to improve learning through writing, a secondary objective was to assist students with time management.

It seems that the weekly tasks may have assisted some students in managing the written work associated with their FYPs (report and portfolio). Forty two per cent of the students who viewed the weekly tasks as positive in the semester 1 questionnaire, linked the usefulness of the tasks to their role in assisting with time management (see Table 6 above). This is further illustrated by the quotations in Table 8 below.

Table 8. A selection of the comments on the questionnaire relating to students perceiving the weekly tasks as useful in terms of time management.

- The weekly tasks reduce workload.

- Useful as allowed workload to be spread out.

- They are good and keep you up-to-date.

- Good idea as they set the ball rolling on specific tasks, e.g. literature review.

- Helped to actually start thinking and working on the written tasks of the project.

- Good idea helps not to get behind.

- Good idea as it gets you to write something, without them I wouldn't have started/known what to do.

- Well structured and relevant to the completion of the project.

- Very good short task to get people thinking about portfolios and reports.

- Good thing they are there to push you to complete different sections by the deadline approaches.

- Keeps work up-to-date and follow deadlines to minimise the load of work. 
- This is very helpful as handing tasks every week pushes you to do the report, part of your project.

- Keeps us on track.

- Helps you do parts of the project as you go along.

- I think weekly tasks really help to get work done on time.

It is interesting to note, however, that the broadly positive perception of weekly tasks in semester 1 may have shifted slightly in semester 2 when the focus group interview was conducted. In fact, the first issue that respondents raised was workload: 'It gets to the point where I think the workload is unhealthy'. Figure 1 shows that the workload issue was linked to both work originating from other modules, as well as the weekly tasks. During the focus group interview there was a fairly heated discussion between a male and a female student relating the link between the weekly tasks and workload:

Male student no. 7: 'In the first semester I asked [the module co-ordinator], look, why are you giving us these extra tasks?'

Female student no. 6: 'I think I wouldn't have done anything if it wasn't for the tasks in the first semester, seriously' [interruption from other female students, murmuring (I agree, a lot of us wouldn't have)]. 'We had the tasks so that, even if you spend, like, one hour on it when you were supposed to spend five, you still have something written there, and then you have the feedback and...you can just put it somewhere until your report comes'.

It was interesting to note that the same male student at a different point in the focus group interview stated: 'I've pretty much done my report work and my portfolio'. The students in the focus group interview also reported time management and writing being important aspects of what they had learned from doing their FYPs (see Table 9). 
Table 9. Answers to the question 'What have you learned in doing your FYP?' from the focus group interview.

\begin{tabular}{|c|c|c|}
\hline Student no. & Student quote & Links to other themes \\
\hline Female 8 & $\begin{array}{l}\text { 'That my time management skills are non- } \\
\text { existent'. }\end{array}$ & Time management \\
\hline Female 10 & 'I think a lot of us can relate to that'. & Time management \\
\hline Female 6 & $\begin{array}{l}\text { 'How to better organise my } \\
\text { programmes... and researching'. }\end{array}$ & $\begin{array}{l}\text { Time management } \\
\text { Research }\end{array}$ \\
\hline Female 9 & 'Different technologies to use...(Java, JSB)'. & Software \\
\hline Male 1 & $\begin{array}{l}\text { 'I learned how to be organised - write things } \\
\text { in advance - it's a } 50 \text { page report, so you } \\
\text { have to know exactly from a long time before } \\
\text { you start what are you gonna do. Also you } \\
\text { learn how to learn by yourself'. }\end{array}$ & $\begin{array}{l}\text { Time management } \\
\text { Writing } \\
\text { Independent study }\end{array}$ \\
\hline Male 4 & $\begin{array}{l}\text { 'I think my organisational skills are better as I } \\
\text { am learning the hard way, because I've got a } \\
\text { lot of work to do. I think it would have been } \\
\text { better if I'd organised myself better in the } \\
\text { earlier semesters. Reflective writing as well - } \\
\text { something that I wasn't very good at. And } \\
\text { programming as well'. }\end{array}$ & $\begin{array}{l}\text { Time management } \\
\text { Writing } \\
\text { Software }\end{array}$ \\
\hline Female 3 & $\begin{array}{l}\text { 'For me just the reflective writing and the } \\
\text { organisational skills. But I do think - I mean I } \\
\text { am not trying to point fingers, but my } \\
\text { organisational skills would have been better } \\
\text { if the support [from my supervisor] was there. } \\
\text { And if we were aware of what was expected } \\
\text { early on in the stage. It's so late on and I still } \\
\text { feel lost, and it's not a good feeling'. }\end{array}$ & $\begin{array}{l}\text { Time management } \\
\text { Writing } \\
\text { Explicitness }\end{array}$ \\
\hline Male 2 & $\begin{array}{l}\text { 'I think I have learned about time } \\
\text { management, you know, how to cope with } \\
\text { pressure - but I am not really coping you } \\
\text { know'. }\end{array}$ & Time management \\
\hline
\end{tabular}


The preceding discussion has concentrated on student perceptions of their time management ability in relation to their written project work. However, the strongest theme to emerge in the focus group interview was students' perceived need for greater support in terms of developing their programming ability in different languages. There was a time management aspect to this theme. Respondents were unanimous in their advice to future FYP students that they should start their FYPs earlier and spend the summer learning a programming language.

\section{Conclusion}

As a returning student, the set up and help in FYP is much better than when here previously. (Student comment from questionnaire)

In this study, computing students were set a series of weekly written tasks relating to their FYPs in the lecture strand of this module. The aim of this intervention was to enhance the quality of students' projects, project reports and time management skills, following a 'learning through writing' approach. The findings from this study seem to show that the students' weekly task marks did have a positive relationship with their project grades. However, the weekly written tasks failed to engage a significant proportion of the cohort and concerns still exist in relation to the supervisors' perceived high tolerance for poor quality writing due to a greater focus on the practical demonstration of the project. It emerged that not all students saw a direct link between the weekly written tasks and their projects. A more pressing issue for students was their perception of a need for greater support with the development of their programming skills. The weekly tasks intervention also failed to make an impact on the 'long tail' of students with lower grades for their projects and project reports. According to Ahearn (2006), as writing is often a technical students' weakest skill, working on writing may affect students' self-esteem and motivation. This may be particularly relevant for students in the cohort who are having difficulty with their subject already. This said, the students who did engage with the weekly written tasks seemed to find the tasks useful for improving their written project report and for managing their time whilst completing a large project. 


\section{Recommendations}

\section{Weekly written tasks could be used in FYP modules}

The weekly tasks discussed in this study seemed useful for improving the quality of students' written work and assisting students in managing their time in completing the written component of the project. In particular, it is recommended that students do the literature review weekly task. Students taking technical courses have particular difficulty writing the literature review section of their project reports and generally receive very little guidance with this section (Krishnan and Kathpalia, 2002). It is recommended, though, that if weekly written tasks are employed, that they should be confined to the first semester of a year long project (to avoid student overload) and that tasks are set after detailed guidance on the tasks has been given.

\section{More emphasis should be placed on written communication and programming in the first and second years of study}

It is common for FYP students to feel overwhelmed as '... professional skills like communication and design are not included until the capstone design course, a point at which a host of skills must be applied simultaneously' (Williams, 2002, p.203). Thus, the degree programme should be looked at as a whole and 'backward design' be employed to ensure that students are equipped to tackle their FYPs without being overloaded. Students could complete mini-projects that emphasise written communication and programming in their first or second year of their degrees (see Daniels et al., 2002). According to the literature these first year 'cornerstone' projects are relatively uncommon at present (Daniels et al., 2002; Ahearn, 2006).

\section{More attention should be paid to exploring the perceived link between the project and its associated written work}

Both students and lecturers in technical subjects may have a different view of the link between their subject and written communication, to learning developers. Lecturers in technical subjects may see writing as a by-product of their work and not an end-product (Ahearn, 2006). It is recommended that this link be explicitly explored with project supervisors (see English et al., 1999) and with students. In addition, students could be set writing tasks that are even more closely linked to their project work. For example, students could be grouped according to the programming languages they are using and could capture their written reflections on programming and implementation using an open-source wiki-based system (Ras et al., 2007). 


\section{References}

Ahearn, A. (2006) 'Replacing writing classes with a writing imperative', in GanobcsikWilliams L. (ed.) Teaching academic writing in UK higher education: theories, practices and models. Basingstoke: Palgrave Macmillan, pp. 110-123.

Bean, J.C. (2011) Engaging ideas: the professor's guide to integrating writing, critical thinking and active learning in the classroom. $2^{\text {nd }}$ edn. San Francisco: John Wiley and sons.

Becker, K. (2008) 'The use of unfamiliar words: writing and CS education', Journal of Computing Sciences in Colleges, 24(2), pp. 13-19.

Bloxham, S. and Boyd, P. (2007) Developing effective assessment in higher education. Maidenhead: McGrawHill/Open University Press.

Carini, R.M., Kuh, G.D. and Klein, S.P. (2006) 'Student engagement and student learning: testing the linkages', Research in Higher Education, 47(1), pp. 1-25.

Cilliers, C.B. (2012) 'Student perception of academic writing skills activities in a traditional programming course', Computers and Education, 58(4), pp. 1028-1041.

Cullen, A. (2012) Module Co-ordinator of the Final Year Project module at the University of Bradford. Personal Communication.

Daniels, M., Faulkner, X. and Newman, I. (2002) 'Open ended group projects, motivating students and preparing them for the real world', IEEE Proceedings of the $15^{\text {th }}$ Conference on Software Engineering Education and Training. Kentucky, USA 25-27 February, pp. 115-126.

Deane, M. and O'Neill, P. (2011a) 'Writing in the disciplines: beyond remediality', in Deane, M. and O'Neill P. (eds.) Writing in the disciplines, pp. 3-11. Basingstoke: Palgrave Macmillan. 
Deane, M. and O'Neill, P. (2011b) 'Conclusions: ways forward for WID', in Deane M. and O’Neill P. (eds.) Writing in the disciplines, pp. 265 - 269. Basingstoke: Palgrave Macmillan.

Dym, C.L. Agogino, A.M. Eirs, O. Frey, D.D. and Leifer, L.J. (2005) 'Engineering design thinking, teaching and Learning', Journal of Engineering Education, January issue, pp. 103-20.

English, L., Bonanno, H., Ihnatko, T., Webb, C. and Jones, J. (1999) 'Learning through writing in a first-year accounting course', Journal of Accounting Education, 17(2-3), pp. 221-254.

External Examiner (2009) Internal report of the External Examiner to the School of Computing, Informatics and Media. University of Bradford.

External Examiner (2010) Internal report of the External Examiner to School of Computing, Informatics and Media. University of Bradford.

Field A.P. (2009) Discovering statistics using SPSS. $3^{\text {rd }}$ edn. London: Sage.

Irons, A. (2008) Enhancing learning through formative assessment and feedback. London: Routledge.

Jawitz, J., Shay, S. and Moore, R. (2002) 'Management and assessment of final year projects in Engineering', International Journal of Engineering Education, 18(4), pp. 472-478.

Kilpatrick, A. (2007) 'On addressing the variation in intellectual demand of engineering undergraduate research project', International Conference on Engineering Education. Coimbra, Portugal 3-7 September.

Kortsarts, Y., Fischbach, A., Rufinus, J., Utell, J.M. and Yoon, S.K. (2010) 'Developing oral and written communication skills in undergraduate computer science and information systems curriculum', Information Systems Journal, 8(30), pp. 3-13. 
Krishnan, L.A. and Kathpalia, S.S. (2002) 'Literature reviews in student reports', IEEE Transactions on Professional Communication, 45(3), pp. 187-197.

Light, R.J. (2001) Making the most of college: students speak their minds. Cambridge: Harvard University Press.

Olsson, B., Berndtsson, M., Lundell, B. and Hansson, J. (2003) 'Running researchoriented final year projects for CS and IS students', ACM SIGCSE Bulletin, 35(1), pp. 79-83.

Project Supervisor A (2010) Email feedback on CM-0347K (July 2010), Module Evaluation of CM-0347K, University of Bradford.

Project Supervisor B (2010) Email feedback on CM-0347K (July 2010), Module Evaluation of CM-0347K, University of Bradford.

Ras, E., Carbon, R., Decker, B. and Rech, J. (2007) 'Experience management wikis for reflective practice in software capstone projects', IEEE Transactions on Education, 50(4), pp. 312-320.

Rasul, M.G., Nouwens, F., Martin, F., Greensill, C., Singh, D., Kestell, C.D. and Hadgraft, R. (2009) 'Good practice guidelines for managing, supervising and assessing final year projects', 20th Australian Association for Engineering Education Conference. University of Adelaide 6-9 December.

Ridley, M. (2012) Head of the School of Computing, Information and Media, University of Bradford. Personal Communication.

Skinner, I. and Mort, P. (2009) 'Embedding academic literacy support within the Electrical Engineering Curriculum: a case study', IEEE Transactions on Education, 52(4), pp. 547-554. 
Teddlie, C. and Tashakkori, A. (2009) Foundations of mixed methods research: integrating quantitative and qualitative approaches in the social and behavioural sciences. USA: Sage.

Williams, J.M. (2002) 'The engineering portfolio: communication, reflection and student learning outcomes assessment', International Journal of Engineering Education, 18(2), pp. 199-207.

Wingate, U. (2006) 'Doing away with 'study skills', Teaching in Higher Education, 11(4), pp. 457-469.

\section{Author details}

Marion Bowman is a Learning Developer in the Learner Development Unit at the University of Bradford. She has been a learning developer for the last five years. Marion is also an experienced teacher of English as a Foreign Language and has lived and worked in a range of different educational environments in the UK, South Africa and Poland.

Andrea Cullen is a Senior Lecturer and Associate Dean (Employer Engagement) in the School of Computing and Media at the University of Bradford. She is the module coordinator for the Final Year Project module and Final Year Tutor. She has past commercial computer programming and systems analysis experience and now teaches Computing at all levels of PG and UG study. She is interested in how students can be better prepared for life after university and works to improve their employment opportunities. 